\title{
Structural Convergence of Economies of Slovak Republic and Czech Republic
}

\author{
Slávka Klasová1 \\ Viliam Kováč 2 \\ František Lipták ${ }^{3}$

\begin{abstract}
1'Ing.; Technical University of Košice, Faculty of Economics, Department of Regional Sciences and Management
2Ing.; Technical University of Košice, Faculty of Economics, Department of Finance

3JUDr. Ing.; University of Pavol Jozef Šafárik, Faculty of Law, Department of Commercial and Business Law
\end{abstract}

\section{Doi:10.5901/mjss.2015.v6n5p235}

\section{Abstract}

The aim of the paper is to identify important factors of development of industrial structure of the Slovak Republic and the Czech Republic economies in the transition process. A multi-industrial analysis focuses on development of inter-industrial structures in terms of gross value added measurement. This paper further quantifies the structural change intensity indicator and the structural deviation indicator, which provide quantitative insight into the formation of the structure of the Slovak economy and the Czech economy. Finally, it offers discussion, gives several proposals of improving weaknesses in the industrial structure of the Slovak economy and express recommendations for current situation.

Keywords: convergence, economy structure, gross value added, structural change intensity, structural deviation.

\section{Introduction}

The issue of industrial structure has become more interesting in connection with emerging process of economic and political integration. The convergence process is well-known to the public, especially due the accession of Slovakia to the European Union. The authors of the various studies have found that integration process supports convergence between members of an integration group.

The mentioned state gives rise to a question whether real or nominal convergence is followed by structural convergence too. Structural convergence can be analysed at inter-industrial and intra-industrial level. The inter-industrial convergence refers to differences of employment shares between three aggregate sectors of an economy - agriculture, industry and services - and thus, concentrate on the shift from agricultural industry to the manufacturing and finally to the service economy. The intra-industrial convergence relates to changes of industrial structures within one of the aggregate sectors, for instance change in the share of the car industry on total manufacturing employment (Höhenberger \& Schmiedeberg, 2008). Wacziarg (1998) summarised two main reasons for paying attention to phenomenon of structural convergence. Firstly, structural convergence influenced international transmission of business cycles. Secondly, studies about structural convergence serve as means for examination of development processes in the longer run and thus, understanding determinants of structural convergence can bring new insight into a model of bilateral trade. In spite of these two main reasons to study structural convergence, the concept has received very little attention among researchers (Imbs \& Wacziarg, 2000). Some work has been done by Landesmann (2000), who scrutinised central and eastern European countries and their structural assimilation and catch-up process. Höhenberger \& Schmiedeberg (2008) analysed structural convergence of fourteen European countries over the period 1970 to 2004. Their results showed that some industries mainly labour intensive and mature, had a tendency to converge over time, while knowledge intensive and emerging industries tend to diverge. Midelfart-Knarvik, Overman \& Venables (2000) investigate structural convergence between European countries. They revealed some specialisation tendencies of European economies and localisation trends of industries from 1970 to 1999.

This paper pays an attention to intra-industrial convergence between the Slovak Republic and the Czech Republic economy structure. By disaggregation of the selected industries paper provides intra-industrial view of the industry structure in order to detect significant mesoeconomic structural changes. The main purpose of this paper is to verify the hypothesis whether the Slovak Republic and the Czech Republic have run the structural convergence process successfully and to assess the structural distortion between the both economies. We chose the Czech Republic as a 
benchmark for our investigation. This analysis is based on the two dimensions - gross value added and employment and covers the period from 1995 to 2010.

\section{Industrial Structure in Transformation Period}

The Czech Republic and Slovakia were part of the communist bloc of the countries in Europe and constituted the Czechoslovak Federation. In 1993, when the Czechoslovak Federation was split into the two independent states, the Czech Republic had better economic structure than the Slovak Republic.

Donnorumo (2006) argues that a strong tourism industry in Prague maintained low unemployment rate and brought money into the country. In addition, the Czech Republic inherited economic structure constituted mainly from mediumsized companies that effectively traded with the surrounding European markets. All these positive factors helped the Czech Republic in its reform during the transition process.

On the contrary, the Slovak Republic inherited heavy industry such as metallurgical industry, arms industry and chemical industry, which were not orientated towards international market but rather domestic market. Therefore, they could not compete in the European markets. The international competitiveness of the Slovak industry sector was not sufficient and as a result industry production decreased. It dramatically appeared in unemployment rate, which was 14.7 \% comparing to about $3.8 \%$ in the Czech Republic in 1993. In spite of these factors, early steps in the Slovak transition focused on higher unemployment rather than on the establishment of market-oriented reforms.

High energy consumption and high dependence on oil and ores imported from the countries of the former Soviet Union arose as a consequence of high dependence on heavy industry. Structural distortions were also manifested in technological backwardness, low performance and efficiency of the economy, poor infrastructure, undersized tertiary sector and lack of production finalisation (Fifeková, 2000). The most important point of the Slovak industrial restructuring process was conversion of the arms industry. In 1994, election stood for reviving and modernising this industry. Many factories took up conversion project, which focused on shift from production of defence products to rubber, chemical and food production. Other civilian projects, for instance construction of hydraulic equipment, building materials, small vehicles had better success in the international markets. Defence industry restructuring was easier in the Czech Republic, because of the presence active small and medium-sized companies network and slow growth of service industries, which were absent in the Slovak Republic. Here, defence restructuring was hugely expensive, as much money was transferred to military companies to write off their debt and to help them in the conversion project. The Slovak economy began to recover from 2001 and became one of the fastest growing economies of the European Union countries between 2005 and 2008 based on the real growth rate (Koyame-Marsh, 2011).

The macroeconomic situation during the period 1993 to 2010

An important factor in the whole transformation process of the Slovak economy was the political environment mainly in 1993 when the authorities of the independent Slovak Republic began to shape the development of economic policy. The beginning of the transformation process was difficult because of poor state of the Slovak economy.

Table 1: Macroeconomic indicators of the Slovak Republic

\begin{tabular}{|c|c|c|c|c|c|c|c|c|}
\hline Year & GDP & GFC & Investment rate & Domestic demand & Import & Export & Inflation rate & Economy openness \\
\hline 1995 & 18.65 & 4.6 & $25 \%$ & 18.39 & 9.83 & 10.06 & $9.9 \%$ & $107 \%$ \\
\hline 1996 & 19.95 & 5.98 & $30 \%$ & 21.52 & 11.53 & 9.92 & $5.8 \%$ & $108 \%$ \\
\hline 1997 & 20.83 & 6.82 & $33 \%$ & 22.67 & 12.44 & 10.5 & $6 \%$ & $110 \%$ \\
\hline 1998 & 21.74 & 7.46 & $34 \%$ & 23.76 & 14.82 & 12.71 & $6.7 \%$ & $127 \%$ \\
\hline 1999 & 21.75 & 6.29 & $29 \%$ & 22.34 & 14.89 & 14.26 & $10.4 \%$ & $134 \%$ \\
\hline 2000 & 22.05 & 5.69 & $26 \%$ & 22.61 & 16.1 & 15.53 & $12.2 \%$ & $144 \%$ \\
\hline 2001 & 22.81 & 6.42 & $28 \%$ & 24.45 & 18.26 & 16.61 & $7.2 \%$ & $153 \%$ \\
\hline 2002 & 23.86 & 6.44 & $27 \%$ & 25.43 & 19.06 & 17.48 & $3.5 \%$ & $153 \%$ \\
\hline 2003 & 25 & 6.26 & $25 \%$ & 25.3 & 20.48 & 20.26 & $8.4 \%$ & $163 \%$ \\
\hline 2004 & 26.26 & 6.56 & $25 \%$ & 26.75 & 22.18 & 21.76 & $7.5 \%$ & $167 \%$ \\
\hline 2005 & 28.01 & 7.71 & $28 \%$ & 29.04 & 24.92 & 23.92 & $2.8 \%$ & $174 \%$ \\
\hline 2006 & 30.35 & 8.43 & $28 \%$ & 30.92 & 29.35 & 28.94 & $4.3 \%$ & $192 \%$ \\
\hline 2007 & 33.53 & 9.19 & $27 \%$ & 32.88 & 32.06 & 33.07 & $1.9 \%$ & $194 \%$ \\
\hline 2008 & 35.46 & 9.28 & $26 \%$ & 34.74 & 33.05 & 34.11 & $3.9 \%$ & $189 \%$ \\
\hline 2009 & 33.71 & 7.45 & $22 \%$ & 32.18 & 27.06 & 28.67 & $0.9 \%$ & $165 \%$ \\
\hline 2010 & 35.12 & 8.37 & $24 \%$ & 33.62 & 31.48 & 33.42 & $0.7 \%$ & $185 \%$ \\
\hline
\end{tabular}


Source: own elaboration based on data from the Eurostat

All these macroeconomic indicators' values are result of changes in the Slovak economy. Since 1993 several reforming legal documents have been ratified, which confirmed market orientation of the Slovak economy. Namely, tax reform, new system of health and pension insurance and establishment of the National Bank of Slovakia belong here. Macroeconomic stability was restored together with strong economic growth in 2000. The Slovak government mitigated the legal system. Improvement of the legal norms devoted to bankruptcy and management of businesses as well as to the gradual reduction of the corporate tax rate from $4 \%$ in 1998 to $25 \%$ in 2002 (Beblavý, 2010). The privatisation of Slovak Power Plants was the largest sale of state controlled corporation in 2002. Such steps were done also in in the transport sector for instance, they involved sale of the Airport Košice, the Railway Company Cargo Slovakia and the bus public transport companies (Kurtyka, 2012).

The subsequent progress of not only economic but also political transformation was quite successful, what was later confirmed by adoption of the Slovak Republic to the European Union in 2004. This was the impetus for implementation of modern political, social and economic system. Adoption of the euro currency completed process of the Slovak Republic integration into the European integration communities in 2009.

Table 2: Macroeconomic indicators of the Czech Republic

\begin{tabular}{|c|c|c|c|c|c|c|c|c|}
\hline Year & GDP & GFC & Investment rate & Domestic demand & Import & Export & Inflation rate & Economy openness \\
\hline 1995 & 58.2 & 17.4 & $30 \%$ & 60.1 & 25.84 & 24.05 & $9.1 \%$ & $86 \%$ \\
\hline 1996 & 60.85 & 18.98 & $31 \%$ & 64.39 & 28.96 & 25.61 & $8.8 \%$ & $90 \%$ \\
\hline 1997 & 60.33 & 17.75 & $29 \%$ & 63.42 & 30.86 & 28.09 & $8.5 \%$ & $98 \%$ \\
\hline 1998 & 60.19 & 17.57 & $30 \%$ & 62.11 & 33.03 & 31.35 & $10.7 \%$ & $107 \%$ \\
\hline 1999 & 61.2 & 17.21 & $28 \%$ & 62.99 & 34.67 & 33.13 & $2 \%$ & $111 \%$ \\
\hline 2000 & 63.76 & 18.32 & $29 \%$ & 65.12 & 40.21 & 38.85 & $3.9 \%$ & $124 \%$ \\
\hline 2001 & 65.73 & 19.14 & $29 \%$ & 67.59 & 45.23 & 43.36 & $4.7 \%$ & $135 \%$ \\
\hline 2002 & 67.14 & 19.88 & $30 \%$ & 70.05 & 47.37 & 44.41 & $1.8 \%$ & $137 \%$ \\
\hline 2003 & 69.67 & 19.99 & $29 \%$ & 72.68 & 50.88 & 47.78 & $0.1 \%$ & $142 \%$ \\
\hline 2004 & 72.98 & 20.59 & $28 \%$ & 74.63 & 55.98 & 54.27 & $2.8 \%$ & $151 \%$ \\
\hline 2005 & 77.91 & 21.83 & $28 \%$ & 76.94 & 59.27 & 60.59 & $1.9 \%$ & $154 \%$ \\
\hline 2006 & 83.38 & 23.1 & $28 \%$ & 80.69 & 65.65 & 68.97 & $2.5 \%$ & $162 \%$ \\
\hline 2007 & 88.16 & 26.15 & $30 \%$ & 86.06 & 74.06 & 76.68 & $2.8 \%$ & $171 \%$ \\
\hline 2008 & 90.89 & 27.23 & $30 \%$ & 87.96 & 76.04 & 79.72 & $6.3 \%$ & $171 \%$ \\
\hline 2009 & 86.62 & 24.1 & $28 \%$ & 82.8 & 67.19 & 71.74 & $1 \%$ & $160 \%$ \\
\hline 2010 & 88.99 & 24.12 & $27 \%$ & 84.43 & 77.97 & 83.53 & $1.5 \%$ & $182 \%$ \\
\hline
\end{tabular}

Source: own elaboration based on data from the Eurostat

Growth of gross domestic product denominated in constant prices in the Czech Republic was not characteristic by permanent increasing trend as it was in the case of the Slovak Republic. There was a transformational recession, which has resulted in decrease of real gross domestic product in the period from 1997 to 1999. The World Bank (2001) considered the economic recession in Germany as a major factor of this decline, because just right Germany was the main export market for the Czech Republic. This transformation recession was not reflected in the Slovak Republic economy. The period from 2000 to the present time is characterised by the growth of gross domestic product at constant prices due to the positive effect of the foreign direct investment inflow, rapid growth of domestic investment and exports, growth supporting economic policy, cultivating institutional environment in terms of the upcoming European Union accession, which occurred in 2004 (Čadil, 2006).

\section{Methodology}

The paper methodology is based on the two key indicators of employment and gross value added. Both variables enter the calculation of the particular structural indicators. Several authors in their studies use just right these indicators for their research (Kuznets, 1973; Melišek, 2001). Employment is measured as the total number of employed in the various sectors on yearly basis. Gross value added at basic prices - marked GVA - is defined as difference between gross production at basic price and manufacturing consumption at purchase price, while the sum of gross value added and 
taxes reduced by subsidies represents the gross domestic product. Manufacturing consumption performs as intermediate consumption in manufacturing process.

The gross value added is an economic indicator that points to the sectors, which produce the biggest amount of money. The best English word describing it is term moneymaker. High degree of specialisation on the basis of gross value added indicates that the country is dependent in certain sectors. One reason for high degree of this specialisation may be the presence of some specific natural resources. Gross value added represents the basic principle for classification of the economic units into the statistical classification NACE - the Statistical Classification of Economic Activities in the European Community, which forms the basement for our analysis. The abbreviation comes from its French name Nomenclature statistique des activités économiques dans la Communauté européenne. This is the main reason to choose the gross value added indicator as an elementary point of our study. It is true that highly specialised field in terms of gross value added can be, but also may not be, dedicated from a point of view of the employment indicator.

There are fifteen industry sectors applied in our analysis that are categorised according to the Statistical Classification of Economic Activities in the European Community with following structure:

- agriculture, hunting and forestry $-A$;

- fishing-B;

- mining and quarrying $-\mathrm{C}$;

- manufacturing - D;

- electricity, gas and water supply - E;

- construction - F;

- wholesale and retail trade - G;

- hotels and restaurants $-\mathrm{H}$;

- transport, storage and communication - I;

- financial intermediation - J;

- real estate, renting and business activities - K;

- public administration and defence - L;

- education - M;

- health and social work - N;

- other activities - 0 .

\section{Data}

Our dataset comes from the database of the Eurostat - the main statistical bureau of the European Union. We handled the figures relating to employment and gross value added at current prices, which comes from the national accounts of the observed countries according to the European System of Accounts - the version ESA 95. The Eurostat provides data for the Czech Republic since 1995 and for the Slovak Republic since 1993. For suitable comparability analysis we took into consideration data from 1995 to 2010, as data availability in this exact form ends at that time. It is caused by adopting new version of the European System of Accounts called ESA 2010.

\section{Structural Change Intensity Indicator}

The indicator of structural change intensity expresses evolution of economic structure, extensiveness and intensity of structural changes in the economy and the ability to adapt in time (Kaderábková \& Srholec, 2001). Higher intensity of structural changes is an accompanying phenomenon of deepening specialisation.

Numerical expression of structural change intensity is following:

$S C I_{S}=\sqrt{\sum_{t=1}^{p}\left(G V A_{S ; t}-G V A_{S ; t-1}\right)^{2} \cdot \frac{G V A_{S ; t-1}}{100}}$

where the comprised indicators mean:

- $\mathrm{SCl}$ - structural change intensity of industry sector S;

- $\mathrm{t}$ - actual period;

- $\quad p$ - number of observed periods;

- GVAs; - gross value added of industry sector $S$ in period $t$;

- GVAs; t - - gross value added of industry sector $S$ in period $t-1$.

The more expansive and the more intensive restructuring processes run, the higher value of this indicator is 
shown. The high value of the indicator obviously means the expansion in the sectors, which are in decline in a global market view or the implementation of such a structural change that is in line with global structural trends. Therefore, not only final values of the indicator should be measured, but also it is needed to identify, what causing such a value of the given indicator. The final argument of square root is divided by number 100 , because of getting per cent value instead of ratio value.

\section{Structural Deviation Indicator}

For comparison industry structure across economies we use the structural deviation indicator. This indicator is a convenient summary measure of the structural adjustment of two or more countries.

The formula is stated as follows:

$S D I_{A ; B}=\sqrt{\sum_{S=1}^{E}\left(O S_{A ; S}-O S_{B ; S}\right)^{2} \cdot \frac{O S_{B ; s}}{100}}$

where the included indicators express:

- $\mathrm{SDI}_{\mathrm{A} ; \mathrm{B}}$ - structural deviation of economies A and B;

- $\mathrm{S}$ - actual industry sector;

- E- number of industry sectors;

- $O S_{A ; s}$ - share of industry sector s output in total output of the economy $A$;

- $\quad \mathrm{OS}_{\mathrm{B} ; \mathrm{s}}$ - share of industry sector $\mathrm{s}$ output in total output of the economy $\mathrm{B}$.

The structural deviation indicator recognises the extent of similarity of two economies (Thiessen \& Gregory, 2005).

The lower value it has, the more structural similarity there is. Also it is applied vice versa with higher value (Havlík, 2005). If its value is very high, it can be understood as structural gap, what means that economy moves away from the global economic trends. Moreover, deepening of structural gap designates unsuitable adaptation of the specific industry to changing condition in the economy (Vincúr et al., 2005).

\section{Results}

This chapter deals with the results of the indicators we chose for our analysis. There is shown the comparison of the Slovak Republic economy and the Czech Republic economy too.

\section{Change of Industry Structure}

Firstly, we should pay attention to the structural change intensity indicator. It reveals interesting evaluation of changes in the economies of the observed countries.

The Slovak Republic had after dissolution of the Czech and Slovak Federative Republic in 1993 different industry structure comparing to the Czech Republic. During the transformation period restructuring process occurred, industrial divisions - agriculture, industry and services - were changing their relative position and the specialisation process was initiated in the Slovak economy. Scope and intensity of structural changes in the Slovak Republic were much stronger than at its neighbour, because it does not inherit proper industry structure, mainly in the field of the heavy machinery industry. To quantify the extent of structural changes we use the indicator of structural changes intensity. The results for the both countries are shown in the successive table.

Table 3: Structural change intensity in the observed countries

\begin{tabular}{|c|c|c|}
\hline Year & Slovak Republic & Czech Republic \\
\hline 1996 & 0.47 & 0.92 \\
\hline 1997 & 1.28 & 0.46 \\
\hline 1998 & 0.18 & 0.58 \\
\hline 1999 & 0.45 & 0.31 \\
\hline 2000 & 0.3 & 0.16 \\
\hline 2001 & 0.36 & 0.06 \\
\hline 2002 & 0.4 & 0.45 \\
\hline 2003 & 0.47 & 0.33 \\
\hline 2004 & 0.45 & 0.86 \\
\hline
\end{tabular}




\begin{tabular}{|c|c|c|}
\hline 2005 & 0.23 & 0.24 \\
\hline 2006 & 0.74 & 0.15 \\
\hline 2007 & 0.23 & 0.08 \\
\hline 2008 & 0.38 & 0.23 \\
\hline 2009 & 1.2 & 0.27 \\
\hline 2010 & 0.18 & 0.04 \\
\hline average value & 0.53 & 0.34 \\
\hline
\end{tabular}

Source: own elaboration based on data from the Eurostat

According to the previous table the mentioned indicator reached significant deviations during the explored period in the Slovak Republic. Because the figures of the displayed indicators are quantified for period of two years and the dataset covers period from 1995 to 2010, they are showed firstly in 1996. The most dynamic structural changes took place in 1997, when this indicator reached value 1.28, and in 2009, when the indicator got value 1.2. In 1997, share of the service sector significantly rose from the level of $55.49 \%$ in 1996 to the level of $59.49 \%$. It is interesting that this structural change was not sufficient to achieve a similar structure to the Czech Republic, as the structural deviation indicator peaked at value of 1.8 in 1997. This was caused by still high share of agriculture sector in the Slovak economy in comparison with the Czech Republic. Higher value in 2009 was triggered due the economic crisis, when all the industrial sectors suffered many problems. The structural deviation indicator between these two economies increased and reached the second highest value of 1.4 in 2009 as a result of the mentioned decline. The structural changes intensity in the Czech Republic was the highest in 1996, when it reached value 0.92 .

Over the explored period the average value of the structural change intensity in the Slovak economy 0.53 exceeded the Czech economy's value 0.34. This confirmed the hypothesis that due to inadequate and deformed economy structure comparing to the Czech Republic's one, which the Slovak Republic inherited after the dissolution of Czechoslovakia, was required more extensive and intensive restructuring just right in the Slovak Republic.

\section{Structural Deviation between Observed Countries}

Each of the explored countries has different structure of their economy and also had various evolutions of their industry sectors throughout the whole observed period from 1995 to 2010. The main aim of the following analysis is to verify whether the structure of the Slovak economy gets more similar to the structure of the Czech economy. There are displayed computed the values of the structural deviation indicator in the successive table.

Table 4: Structural deviation indicator between the observed countries

\begin{tabular}{|c|c|}
\hline Year & Structural deviation indicator \\
\hline 1996 & 0.9 \\
\hline 1997 & 1 \\
\hline 1998 & 1.8 \\
\hline 1999 & 1.5 \\
\hline 2000 & 1.1 \\
\hline 2001 & 0.9 \\
\hline 2002 & 1.2 \\
\hline 2003 & 0.6 \\
\hline 2004 & 0.8 \\
\hline 2005 & 0.8 \\
\hline 2006 & 0.4 \\
\hline 2007 & 0.4 \\
\hline 2008 & 0.4 \\
\hline 2009 & 1.4 \\
\hline 2010 & 1.3 \\
\hline average value & 0.97 \\
\hline
\end{tabular}

Source: own elaboration based on data from the Eurostat 
The next step of the analysis is to examine the structural disparities in inter-industry level and to clear up the main reasons of their incidence. In the next table the structural profile of the both countries is compared.

Table 5: Structural profile of the explored economies

\begin{tabular}{|c|c|c|c|c|c|c|}
\hline \multirow{2}{*}{ Sector } & \multicolumn{3}{|c|}{ Slovak economy } & \multicolumn{3}{c|}{ Czech economy } \\
\cline { 2 - 7 } & 1995 & 2010 & Change & 1995 & 2010 & Change \\
\hline A & 5.91 & 3.51 & $-2.4 \%$ & 4.71 & 1.98 & $-2.73 \%$ \\
\hline B & 0.004 & 0.005 & $0.001 \%$ & 0.048 & 8 & $-0.04 \%$ \\
\hline C & 1.4 & 0.66 & $-0.39 \%$ & 2.1 & 1.29 & $-0.81 \%$ \\
\hline D & 26.78 & 19.36 & $-7.43 \%$ & 23.9 & 23.18 & $0.09 \%$ \\
\hline E & 4.84 & 5.59 & $0.75 \%$ & 5.1 & 5.61 & $0.6 \%$ \\
\hline F & 5.1 & 9.51 & $4.4 \%$ & 6.26 & 7.2 & $0.76 \%$ \\
\hline G & 12.43 & 15.44 & $3 \%$ & 10.6 & 12.47 & $1.88 \%$ \\
\hline H & 1.64 & 1.31 & $-0.32 \%$ & 2.69 & 1.87 & $-0.82 \%$ \\
\hline I & 10.51 & 7.18 & $-3.34 \%$ & 9.91 & 10.28 & $0.36 \%$ \\
\hline J & 5.69 & 4.57 & $-1.12 \%$ & 3.6 & 3.46 & $0.4 \%$ \\
\hline K & 11.76 & 14.75 & $2.99 \%$ & 12.98 & 13.78 & $0.8 \%$ \\
\hline L & 5.18 & 7.15 & $1.97 \%$ & 5.14 & 5.15 & $0.005 \%$ \\
\hline M & 3.48 & 3.6 & $0.12 \%$ & 3.86 & 4.22 & $0.37 \%$ \\
\hline N & 3.43 & 3.56 & $0.13 \%$ & 3.35 & 4.27 & $0.92 \%$ \\
\hline O & 2.2 & 3.69 & $1.5 \%$ & 2.36 & 2.92 & $0.56 \%$ \\
\hline
\end{tabular}

Source: own elaboration based on data from the Eurostat

Slovakia recorded the structural shifts in line with the structural trends in the Czech Republic, although their dynamics was different. The increase of the gross value added share of wholesale and retail trade $-G$ sector, real estate and business activities $-\mathrm{K}$ sector, construction $-\mathrm{F}$ sector and public administration $-\mathrm{L}$ sector was substantially larger than the Czech increase. These industry sectors achieved much higher proportions of gross value added in the Slovak republic than in the Czech Republic. According to their shares on the total gross value added value, they seem to be oversized sectors. On the other hand, dynamic structural change leading to growth in education - $M$ sector and health and social work - $\mathrm{N}$ sector occurred in the both countries, nevertheless there is much lower share of gross value added in these sectors in the Slovak economy than in the Czech economy. In concordance with the historic experience of developed countries the share of agriculture - A sector has continuously declined in the both countries. Due to slower decline in the Slovak Republic this sector is still oversized compared with the Czech Republic. Another factor of structural deviation is the fact that the Slovak economy did not capture the structural trends, which the Czech economy undertook for instance growth in the share of transport, storage and communication - I sector, financial intermediation - J sector and manufacturing - D sector. Based on the above mentioned causes, it is possible to classify industries that are undersized or oversized in comparison of these two countries.

On the one hand, oversized industry sectors are agriculture - A sector, wholesale and retail trade - $\mathrm{G}$ sector, construction - $\mathrm{F}$ sector, public administration - $\mathrm{L}$ sector, real estate and business activities $-\mathrm{K}$ sector and other services - $\mathrm{O}$ sector. On the other hand, undersized sectors are industries are education - M sector, health and social work $-\mathrm{N}$ sector, transport and communication - I sector and manufacturing - D sector.

\section{Discussion and Conclusions}

A detailed analysis of the sectorial structure of the Slovak Republic economy and the Czech Republic economy on the basis of gross value added provided us with a comprehensive view of the evolution of the structural profile of these countries' industries during the transformation period from 1995 to 2010. We found significant differences, but also similarities in the sectorial structure, which contribute to change of a structural gap between these two economies.

Based on carried on intra-sectorial and inter-sectorial analyses, we are able to confirm that there is structural convergence between the Slovak Republic and the Czech Republic. Its presence is conditioned by gradual approaching to the structural profile of the Czech Republic. In 1995, the Slovak economy had significantly different sectorial structure, but by capturing the important global structural trends similar structure to the Czech Republic's one was reached. Examination demonstrated the existence of structural convergence during the period 2003 to 2008, as the value of 
structural deviation indicator declined. Of course, there are some problems associated with structural convergence, which we pointed out that caused significant deviations from the standard structural profile of the country.

\section{Recommendations}

The appropriateness of the focus on issues related to the development of structural profiles is confirmed by several studies devoted to phenomenon of structural convergence. Countries differ in terms of conditions to constitute their industry structure. They should create favourable conditions for the successful adaptation of economic subjects to the structural trends in order to enhance environment for suitably operating economy. New sectorial structure has become an aspect of economic growth and development of each country in the recent period. Regarding this, it would be appropriate to point out the importance of knowledge of structural gap. Usually, the process of structural convergence between the countries will never be completed as a certain degree of structural differentiation between countries will always be present due to discrepancies in size of economy, factor endowments, culture or in variances in institutional framework. In this case, countries should focus on intensive type of growth, whose sources are research and development, health, social work and education sector.

\section{Bibliography}

Beblavý, M. (2010). Slovakia's transition to a market economy and the World Bank's engagement. [Online] Available: http://papers.ssrn. com/sol3/Delivery.cfm/SSRN_ID1530284_code367436.pdf?abstractid=1530284\&mirid=1 (May 15, 2015).

Čadil, V. (2006). Strukturální analýza české ekonomiky pro prípravu NPV III.

Donnorummo, B. (2006). The Political and Economic Complexities of Transition. Zagreb International Review of Economics \& Business, 3, 13-27. [Online] Available: http://hrcak.srce.hr/file/116793 (May 15, 2015).

Fifeková, E. (2000). Základné príčiny nedostatočnej štruktúrnej adaptácie a pomalého rastu konkurencieschopnosti slovenskej ekonomiky v transformačnom období. In: Transformácia ekonomiky Slovenskej republiky, 21-33.

Havlík, P. (2005): Structural Change, Productivity and Employment in the New EU Member States. Wiener Institut für International Wirtschaftsvergleiche Research Reports, 313, 1-45. [Online] Available: http://www.wiiw.ac.at/modPubl/download.php?publ= RR313 (May 15, 2015).

Höhenberger, N. \& Schmiedeberg, C. (2008). Structural Convergence of European Countries. Center for European Governance and Economic Development Discussion Papers, 75, 1-41. [Online] Available: http://wwwuser.gwdg.de/ cege/Diskussionspapiere/75 (May 15, 2015).

Imbs, J. \& Wacziarg, R. (2000). Stages of Diversification. Centre for Economic Policy Research, DP2642.

Kadeřábková, A. \& Srholec, M. (2001). Structural Changes in Transition Economies. Prague Economic Papers, 4, 335-351. [Online] Available:

http://www.researchgate.net/profile/Martin_Srholec/publication/227473388_Structural_changes_in_transitive_economies/links/54 7e24580cf2de80e7cc5314.pdf (May 15, 2015).

Koyame-Marsh, R. (2011). The Complexities of Economic Transition: Lesson from the Czech Republic and Slovakia. International Journal of Business and Social Science, 19, 71-85. [Online] Available: http:/lijbssnet.com/journals/Vol_2_No_19_Special_ Issue_October_2011/8.pdf (May 15, 2015).

Kuznets, S. (1973). Modern Economic Growth: Findings and Reflections. American Economic Review, 3, 247-258.

Kurtyka, M. (2015). Štúdia reštrukturalizácie v nových členských štátoch. [Online] Available: http://resourcecentre.etuc.org/ReportFile20080229110141_Restructuring-Slovakia-country-dossier-SK[1].pdf (May 15, 2015).

Landesmann, M. (2000). Structural Change in the Transition Economies, 1989 to 1999. [Online] Available: http://www.econ.jku.at/ members/Landesmann/files/Workingpapers/WIIW\%20Research\%20Report\%20269a.pdf (May 15, 2015).

Melišek, F. (2001). Štruktúrna politika ako významný fenomén ekonomického rastu a stability ekonomiky. Ekonomické rozhlady, 2, 228238.

Midelfart-Knarvik, K.H., Overman, H.G. \& A. J. Venables. (2000). Comparative advantage and economic geography: estimating the determinants of industrial location in the EU. Centre for Economic Policy Research, DP2618. [Online] Available: http://personal. Ise.ac.uk/overman/research/mkov.pdf (May 15, 2015).

Thiessen, U. \& Gregory, P. (2005). Modelling the Structural Change of Transition Countries. German Institute for Economic Research Discussion Papers, 519, 1-40. [Online] Available: http://www.diw.de/documents/publikationen/73/diw_01.c.43753.de/dp519.pdf (May 15, 2015).

Vincúr et al. (2005). Teória a prax hospodárskej politiky. Bratislava: Sprint vfra.

Wacziarg, R. (1998). Measuring the Dynamic Gains from Trade. Policy Research Working Paper Series, 2001, 1-57. [Online] Available: http://www-wds.worldbank.org/servlet/WDSContentServer/WDSP/IB/2000/02/24/000094946_99031911104024/Rendered/PDF/ multi_page.pdf (May 15, 2015).

World Bank. (2001). Slovak Republic, Living Standards, Employment and Labor Market Study. [Online] Available: http://www-wds. worldbank.org/external/default/WDSContentServer/WDSP/IB/2001/09/28/000094946_01092004005284/Rendered/PDF/multiopa ge.pdf (May 15, 2015). 